\title{
Expression and functionality of histone H2A variants in cancer
}

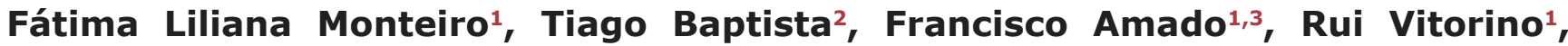 \\ Carmen Jerónimo ${ }^{2,4}$ and Luisa A. Helguero ${ }^{1}$ \\ ${ }^{1}$ Mass Specrometry Center, Organic Chemistry and Natural Products Unit (QOPNA), Dep. of Chemistry, Universidade de \\ Aveiro., Aveiro, Portugal \\ ${ }^{2}$ Cancer Biology \& Epigenetics Group, Research Center Portuguese Oncology Institute - Porto. Porto, Portugal \\ ${ }^{3}$ School of Health Sciences, Universidade de Aveiro., Portugal \\ ${ }^{4}$ Department of Pathology and Molecular Immunology, Institute of Biomedical Sciences Abel Salazar (ICBAS) - University \\ of Porto, Porto, Portugal
}

Correspondence to: Luisa A. Helguero, email: luisa.helguero@va.pt

Keywords: epigenetics, post-translational modifications, histone H2A, cancer.

Received: April 8, $2014 \quad$ Accepted: May 24, $2014 \quad$ Published: May 26, 2014

This is an open-access article distributed under the terms of the Creative Commons Attribution License, which permits unrestricted use, distribution, and reproduction in any medium, provided the original author and source are credited.

\section{ABSTRACT}

Regulation of gene expression includes the replacement of canonical histones for non-allelic histone variants, as well as their multiple targeting by postranslational modifications. H2A variants are highly conserved between species suggesting they execute important functions that cannot be accomplished by canonical histones. Altered expression of many H2A variants is associated to cancer. MacroH2A variants are enriched in heterocromatic foci and are necessary for chromatin condensation. MacroH2A1.1 and macroH2A1.2 are two mutually exclusive isoforms. MacroH2A1.1 and macroH2A2 inhibit proliferation and are associated with better cancer prognosis; while macroH2A1.2 is associated to cancer progression. H2AX variant functions as a sensor of DNA damage and defines the cellular response towards DNA repair or apoptosis; therefore, screening approaches and therapeutic options targeting H2AX have been proposed. H2A.Z is enriched in euchromatin, acting as a protooncogene with established roles in hormone responsive cancers and overexpressed in endocrine-resistant disease. Other H2A family members have also been found altered in cancer, but their function remains unknown. Substantial progress has been made to understand histone H2A variants, their contribution to normal cellular function and to cancer development and progression. Yet, implementation of high resolution mass spectrometry is needed to further our knowledge on highly homologous H2A variants expression and function.

\section{INTRODUCTION}

Genomic DNA in eukaryotic cells is packaged into chromatin being the nucleosome the smallest subunit. Nucleosomes consist of 145-147 base pairs of DNA wrapped around an octamer of core histone proteins which usually includes two molecules of each of the canonical core histones: H2A, H2B, H3 and H4. These are assembled in one central $\mathrm{H} 3-\mathrm{H} 4$ heterotetramer and two H2A-H2B heterodimers [1, 2] with the linker histone H1 holding the nucleosome together [3]. The highly dynamic changes in nucleosome composition and in their biochemical properties allows regulation of transcription, gene silencing, DNA replication and recombination [4]. Regulation of gene expression at the nucleosome level occurs through combinatorial effects of epigenetic marks including DNA methylation, core histone posttranslational modifications (hPTMs) [5] and incorporation of diverse replacement histone variants [6]. While DNA methylation and hPTMs have been the focus of intensive research, much less is known about the mechanisms of core histone replacement and their function. Histones are among the most highly conserved proteins in terms of sequence and structure [7] and replacement of histone variants has been described for all core histone subtypes except histone H4 [4]. Major-type core histones make up the majority of nucleosomes during replication and their expression is tightly coupled to $\mathrm{S}$ phase $[8,9]$. On the other hand, histone variants are distinct non-allelic forms of core histones, their expression is not restricted to the S-phase, and they are incorporated into nucleosomes through DNA replication-independent mechanisms that often involve specific histone chaperones and ATP-dependent chromatin remodelling factors [10-12]. Substitution of one or more of the core histones with the corresponding non-allelic variants results in differences in nucleosome stability and biochemical properties, thus altering chromatin structure and accessibility of transcription factors and chromatin 
Table 1 : Histone variants, their known functions and alterations in distinct types of cancer Histone variant (gene/s)

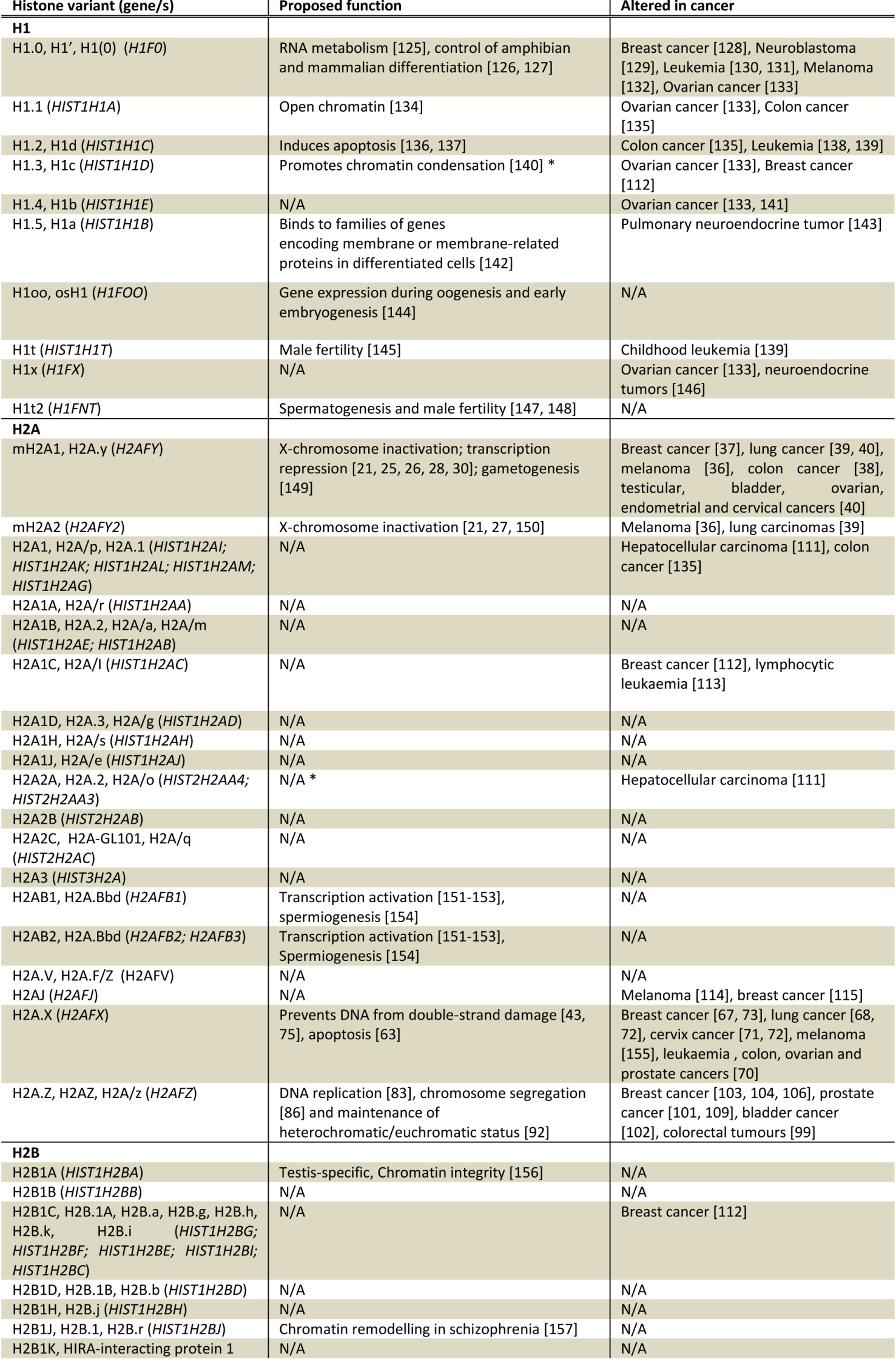




\begin{tabular}{|c|c|c|}
\hline \multicolumn{3}{|l|}{ (HIST1H2BK) } \\
\hline H2B1L, H2B.c (HIST1H2BL) & N/A & Gastric cancer [158] \\
\hline H2B1M, H2B.e (HIST1H2BM) & N/A & Breast cancer [159] \\
\hline H2B1N, H2B.d (HIST1H2BN) & N/A & $\mathrm{N} / \mathrm{A}$ \\
\hline H2B1O, H2B.2, H2B.n (HIST1H2BO) & N/A & $\begin{array}{l}\text { Breast cancer [112], acute myeloid } \\
\text { leukemia [160] }\end{array}$ \\
\hline $\begin{array}{l}\text { H2B2E, H2B-GL105, H2B.q } \\
(H I S T 2 H 2 B E)\end{array}$ & $\begin{array}{l}\text { Inhibits cell proliferation [161], inactive odour- } \\
\text { sensing neurons [162] }\end{array}$ & Gastric cancer $[161]$ \\
\hline $\mathrm{H} 2 \mathrm{~B} 2 \mathrm{~F}(H I S T 2 H 2 B F)$ & N/A & Prostate cancer [163] \\
\hline H2B3B, H2B type 12 (HIST3H2BB) & $N / A$ & $\mathrm{~N} / \mathrm{A}$ \\
\hline H2BFM, H2B.s (H2BFM) & N/A & $\mathrm{N} / \mathrm{A}$ \\
\hline H2BFS, H2B.s (H2BFS) & N/A & $N / A$ \\
\hline H2BWT $(H 2 B F W T)$ & Telomeric preservation during mitosis (164) & $\mathrm{N} / \mathrm{A}$ \\
\hline \multicolumn{3}{|c|}{ 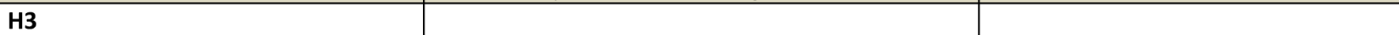 } \\
\hline $\begin{array}{l}\text { H3.1 (HIST1H3A; HIST1H3D; } \\
\text { HIST1H3C; HIST1H3E; HIST1H3I; } \\
\text { HIST1H3G; HIST1H3J; HIST1H3H; } \\
\text { HIST1H3B; HIST1H3F) }\end{array}$ & $\begin{array}{l}\text { DNA replication and repair [164], cell } \\
\text { differentiation [165] }\end{array}$ & Colon cancer [135] \\
\hline $\begin{array}{l}\mathrm{H} 3.2, \mathrm{H} 3 / \mathrm{m}, \mathrm{H} 3 / \mathrm{O}(\mathrm{HIST} 2 \mathrm{H} 3 \mathrm{C} ; \\
\text { HIST2H3A; HIST2H3D) }\end{array}$ & N/A & Colon cancer [135] \\
\hline H3.3 (H3F3A; H3F3B) & Transcription activation $(165,166,167)$ & $\begin{array}{l}\text { Acute myeloid leukemia [160], breast } \\
\text { cancer [166] }\end{array}$ \\
\hline $\mathrm{H} 3.1 \mathrm{t}, \mathrm{H3} / \mathrm{g}, \mathrm{H} 3 \mathrm{t}, \mathrm{H} 3 / \mathrm{t},(\mathrm{HIST} 3 \mathrm{H} 3)$ & $\begin{array}{l}\text { Chromatin reorganization during meiosis and/or } \\
\text { spermatogenesis [167] }\end{array}$ & $\mathrm{N} / \mathrm{A}$ \\
\hline H3.3C, H3.5 (H3F3C) & Active chromatin [168] & $\mathrm{N} / \mathrm{A}$ \\
\hline CENP-A (CENPA) & Kinetochore assembly [169-171]; mitosis [172] & $\begin{array}{l}\text { Human testicular germ cell tumours } \\
\text { [173], hepatocellular carcinoma [174], } \\
\text { colorectal cancer [175], breast cancer } \\
\text { [176] }\end{array}$ \\
\hline
\end{tabular}

remodelers to the DNA $[13,14]$.

Histone variants are highly conserved between different species [15-17], indicating that they have evolved to fulfill important functions that cannot be accomplished by canonical histones [14]. There are several examples of highly divergent replacement variants which have specialized functions and whose deregulation can contribute to cancer development (Table 1). The H2A family of replacement histone variants comprises the largest number of genes identified found associated with cancer, as recently reviewed [18]. H2A variants differ mainly in their $\mathrm{N}$ - and $\mathrm{C}$-terminal sequence, whereas the core region is highly conserved [19]. Currently, there are over $19 \mathrm{H} 2 \mathrm{~A}$ histone variants identified in human and mouse. They share high degree of homology in their nucleotide and amino acid sequence (Supplementary Tables 1 and 2). This review focuses on $\mathrm{H} 2 \mathrm{~A}$ histone variants which are altered in cancer; describes their functions, and the methodological difficulties faced in the analysis of many members of the H2A family.

\section{macroH2A histone variants}

MacroH2A is an extremely divergent $\mathrm{H} 2 \mathrm{~A}$ variant with a tripartite structure consisting of an amino-terminal histone-like region that is $64 \%$ identical in the amino acid

sequence to full length histone $\mathrm{H} 2 \mathrm{~A}$, a large carboxyl-terminal globular domain and the macro domain which is a lysine $(\mathrm{K})$ rich H1-like linker region that includes a random coil with no similarity to other histones $[15,20]$. Two macroH2 $\mathrm{A}$ genes are present in vertebrates, $H 2 A F Y$ and $H 2 A F Y 2$, which encode macroH2A1 and
macroH2A2 proteins, respectively [21]. Several PTMs have been identified on histone macroH2A1, mostly in the N-terminal domain (Fig. 1A) [22-25].

Constanzi et al. originally found macroH2 $\mathrm{A} 1$ as enriched in inactive $\mathrm{X}$ chromosome $(\mathrm{Xi})$ in female mouse, dog and human [26]. A few years later, macroH2A2 was also identified in $X i$ chromosome [21, 27]. MacroH2A1 occupies $25 \%$ of the human genome and is incorporated into nucleosomes found in heterochromatin. Its ubiquitination by the CULLIN3/speckle-Type POZ Protein (SPOP) E3 ligase complex results in stable $\mathrm{X}$ chromosome inactivation in mammalian females [25]. Several independent observations support the idea that the enrichment of macroH2A in the nucleosome correlates with heterochromatin and gene silencing. Namely, macroH2A interferes with transcription factor binding and nucleosome remodelling by SWI/SNF complexes [28]; enrichment of macroH2A1 is associated to the facultative H3K27me3 heterochromatin mark and to the depletion of active transcription marks such as RNA polymerase II, H3K4me1, and histone $\mathrm{H} 3$ acetylation; macroH2A1 is mainly localized near transcription start sites (TSSs) and CTCF-binding sites [29] and is enriched in transcriptionally silent senescence-associated heterochromatic foci [30]. MacroH2A proteins constitute a repressive mark that contributes to the fine-tuning of temporal activation of $H O X A$ cluster genes during neuronal differentiation and its loss in zebrafish embryos leads to severe developmental defects [31]. Therefore, macroH2A variants constitute an important epigenetic mark involved in the concerted regulation of gene expression programs during cellular differentiation and vertebrate development 
[31]. On the other hand, macroH2A can be phosphorylated by Cdk complexes, containing cyclin $\mathrm{E}$ and cyclin $\mathrm{B}$. Consequently, macroH2A-phSer137 is excluded from heterochromatin in Xi chromosome and is enriched in heterochromatin during mitosis, suggesting it may play a role in cell cycle regulation [22].

Contrary, to its enrichment in heterochromatin, macroH2A positively regulates a subset of specific genes associated with lipid metabolism during liver transition from newborn to young-adult state [32]. In line with this work, macroH2A1 is likely found in promoter-proximal regions in IMR90 human primary lung fibroblasts and MCF-7 breast cancer cells and can also increase signalregulated transcription, specifically for genes activated by serum starvation [29].

The $H 2 A F Y$ gene contains two mutually exclusive exons which can be alternatively spliced to originate two isoforms, macroH2A1.1 and macroH2A1.2 (Fig. 1B) [27, 33], differing only in a part of the non-histone region [34]. MacroH2A1.1 splice variant is mostly restricted to differentiated cells $[33,34]$ and can bind to nicotinamide adenine dinucleotide (NAD) ${ }^{+}$-derived ligands; while macroH2A1.2 cannot interact with these small molecules [35], it is generally expressed in embryonic stem cells and the early embryo $[27,33,34]$.

\section{Histone macroH2A in cancer}

MacroH2A variant expression is majorly lost in melanoma progression, mainly through promoter methylation, as shown for macroH2A2 in metastatic disease [36]. In addition, macroH2A1 suppresses melanoma progression through downregulation of cyclindependent kinase 8 (CDK8) gene expression, which promotes cellular proliferation through enhancement of malignant transformation by $\beta$-catenin [36]. While in normal adult cells macroH2A1 isoforms are expressed with similar levels, macroH2A1.1 decreases in a variety of human cancers including breast [37], colorectal [38], lung $[39,40]$, testis, bladder, ovarian, endometrial and cervical cancers [40]; and the ratio macroH2A1.1 / macroH2A1.2 has a profound effect on patient prognosis and survival. In cancers with poor prognosis, alternative splicing of the $H 2 A F Y$ gene strongly favours macroH2A1.2 expression, due to decreased activity of the splicing factor QKI [39, 40]. MacroH2A1.1 is highly expressed in tumours with better prognosis and low mitotic index [39]; while its low levels correlate to tumours undergoing rapid cell division marked by high expression of the proliferation marker Ki67 [39]. Moreover, macroH2A1.1 downregulation favours metastasis and correlates with decreased patient survival and tumour recurrence, as shown in lung cancer [39]. Furthermore, macroH2A1.1 is upregulated in senescent cells and triggers oncogene-induced senescence [30].

Poly (ADP-Ribose) Polymerase 1 (PARP-1) has been implicated in several processes that promote cellular proliferation of lung and cervical cancer cells. Their growth suppression is at least in part, mediated by macroH2A1.1 interaction with PARP-1 and its subsequent downregulation [40]. MacroH2A1.1 not only acts as a transcriptional repressor as in the case of the oncogene c-Fos [41], but it also promotes the expression of proteins involved in redox metabolism, such as Superoxide Dismutase 3, Extracellular (SOD3), Hydroxyacid Oxidase (Glycolate Oxidase) 1 (HAOl), Rieske (FeS) Domain Containing (RFESD) and Glucose-Fructose Oxidoreductase Domain Containing 1 (GFOD1) [42] (Fig. 1B). Depletion of macroH2A1.2 in metastatic 4T1 cells, which under normal conditions display a higher content of macroH2A1.2 in detriment of macroH21.1, induces SOD3 expression. In a similar way, depletion of macroH2A1.1 in non-metastatic cells 67NR, which have a high macroH2A1.1/macroH2A1.2 ratio, SOD3 was also induced, suggesting that macroH2A1.1 is able to promote SOD3 expression, while macroH2A1.2 inhibits it [42]. Also, macroH2A1.2 is by far the predominant form in MCF-7 breast cancer cell line [29] and can interact with HER-2 in the nucleus to enhance the over-expression of oncogene ERBB2 [37] (Fig. 1B). Therefore, while it is generally accepted that histones macroH2A1.1 and macroH2A 2 act as tumour suppressors, macroH2A 1.2 variant seems to be an oncogene associated with disease progression and negative patient outcome.

The varying array of biological processes regulated by macroH2A histones can be inferred from their network of interacting proteins including positive and negative regulators of transcription (Fig. 1C). Interestingly, one of the major advantages of cancer cells compared to nonmalignant cells is their ability to adapt their metabolism to the nutrient availability. Thus, identification and understanding the macroH $2 \mathrm{~A}$ protein complexes that regulate genes in redox metabolism such as $S O D 3$ as well as lipid metabolism genes deserves further study.

\section{H2AX histone variant}

$\mathrm{H} 2 \mathrm{AX}$ levels are cell line or tissue specific and represent about $2-25 \%$ of total $\mathrm{H} 2 \mathrm{~A}$ [43]. In contrast to other genes encoding $\mathrm{H} 2 \mathrm{~A}$ histone variants, $H 2 A F X$ contains landscapes of both replication dependent and replication-independent histone species [44]. It has been proposed that this dual mechanism of translational regulation ensures the presence of sufficient $\mathrm{H} 2 \mathrm{AX}$ molecules in the replicating genome for efficient and continued presence of $\mathrm{H} 2 \mathrm{AX}$ at G1 and G0 phase of the cell cycle [45].

The main function of $\mathrm{H} 2 \mathrm{AX}$ is associated with the DNA damage repair (DDR) system which is induced by DNA double strand breaks (DSBs) (Fig. 2A), being H2AX function regulated by multiple PTMs (Fig. 2B). One of the first responses to DSBs in eukaryotic cells is the phosphorylation of serine 139 in the C-terminal tail 
of histone H2AX. This yields a specific modified form known as $\gamma \mathrm{H} 2 \mathrm{AX}$, and promotes recruitment of DNA repair proteins to sites of DSBs $[43,46]$, leading to a linear increase in the number of $\gamma \mathrm{H} 2 \mathrm{AX}$ molecules with the severity of the DNA damage. Therefore, $\gamma \mathrm{H} 2 \mathrm{AX}$ has been used as a sensitive marker for the presence of DSBs in cells and tissues [43]. H2AX can also be acetylated in K36 by the $\mathrm{CBP} / \mathrm{p} 300$ acetyltransferases [47] and in threonine (Thr) 101 [48]. These two PTMs are required for cells to survive exposure to ionizing radiation (IR) independently of H2AX phosphorylation [48].

A

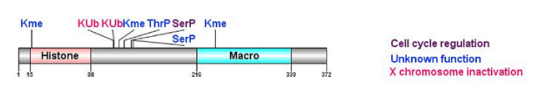

B

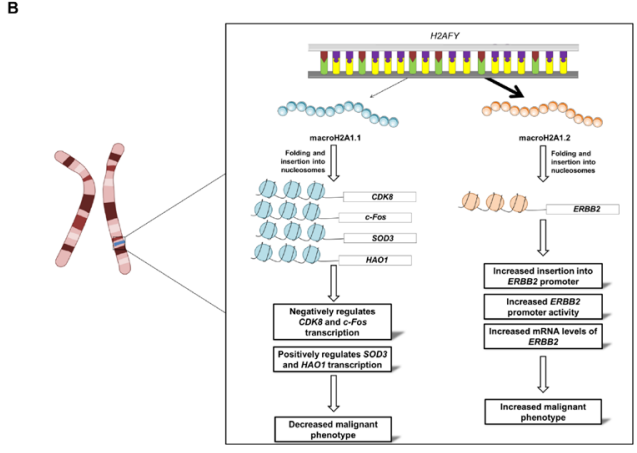

c
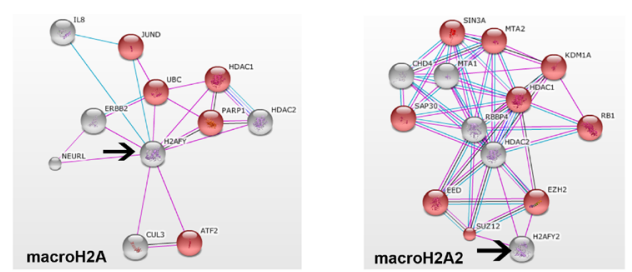

Figure 1: Role of $H 2 A F Y$ and $H 2 A F Y 2$ in cancer progression. A. Structural domains and postranslational modifications identified on macroH2A.1 protein [22-25]. B. Alternative splicing of $H 2 A F Y$ gives rise to macroH2A1.1 and macroH2A1.2 isoforms. Their incorporation into nucleosomes of specific genes exerts different effects. MacroH2A1.1 negatively impacts cancer progression through inhibition of expression of genes that stimulate cell proliferation $(C D K 8$ and $c-F O S$ ) and involved in redox metabolism (SOD3 and HAO1).On the othe hand, macroH2A1.2 substitution in ERBB2 oncogene promoter stimulates its expression. C. Protein interaction network obtained from String DB (string-db.org) illustrates one of the possible biological processes regulated, as inferred from analysis of public databases. Both macroH2A variants (arrows) can differentially interact with histone modifying proteins and transcription factors which results in regulation of a variety of biological processes. One differential regulation is highlighted in red, where macroH2A1 interactors influence gene expression $(\mathrm{p}<0.016)$, while macroH2A2 inhibit transcription $(\mathrm{p}<1.05$ $\left.\mathrm{x} 10^{-5}\right)$. Grids were obtained using a confidence score of 0.6. Colour key: pink $=$ experimental evidence; blue $=$ evidence from databases; black $=$ co-expression.
$\mathrm{H} 2 \mathrm{AX}$ phosphorylation is catalysed by three phosphatidylinositol-3 kinase-like kinases (PIKKs): ataxia telangiectasia mutated (ATM), ataxia telangiectasia and Rad3-related (ATR) and DNA-dependent protein kinase (DNA-PK) [49, 50]. A signal amplification loop involving $\mathrm{H} 2 \mathrm{AX}$, Nijmegen breakage syndrome 1 (nibrin- NBS1) and mediator of DNA damage checkpoint protein 1 (MDC1) stimulates ATM and increases H2AX phosphorylation [51]. NBS1 and MDC1 bind directly to $\gamma \mathrm{H} 2 \mathrm{AX}$ through MDC1 BRCT domain, which allows the accumulation of DDR proteins including the MRN (MRE11-RAD50-NBS1) complex, Ring Finger Protein 8, E3 Ubiquitin Protein Ligase (RNF8), Breast Cancer 1, Early Onset (BRCA1) and p53-binding protein 1 (53BP1) [52-54]. In addition, DSBs facilitate TIP60 and UbiquitinConjugating Enzyme E2N (UBC13) association and further ATM acetylation and activation as well as H2AX acetylation in K5-independently of its phosphorylation [55]. Consequently, H2AX is released from chromatin and it is ubiquitylated on K119 by UBC13 [55]. Ring Finger Protein 168, E3 Ubiquitin Protein Ligase (RNF168) and RNF8 also ubiquitylate $\mathrm{H} 2 \mathrm{AX}$ on $\mathrm{K} 13, \mathrm{~K} 15, \mathrm{~K} 118$ and $\mathrm{K} 119$, which initiate the formation of ubiquitin chains and recruitment of various DDR proteins containing ubiquitinbinding domain [55-60]. The H2AX ubiquitination by RNF168 and RING1B/BMI is mediated by the nucleosome acid patch which is also required for RNF168and RING1B/BMI- dependent DDR proteins recruitment to repair DNA damage [61]. Although it is generally accepted that DNA DSBs induce the formation of $\gamma \mathrm{H} 2 \mathrm{AX}$ foci, DNA single-stranded regions induced by ultraviolet $\mathrm{C}$ irradiation can also induce formation of $\gamma \mathrm{H} 2 \mathrm{AX}$ [50]. Furthermore, in apoptosis provoked by UV irradiation, $\gamma \mathrm{H} 2 \mathrm{AX}$ may be further phosphorylated by c-Jun NH2terminal kinase (JNK) [62] and function as a response to endonuclease-mediated DNA fragmentation downstream from caspase-3/caspase-activated DNase (CAD) pathway activation [63]. More recent studies reveal that the decision to undergo DDR or apoptosis is determined by phosphorylation of $\gamma \mathrm{H} 2 \mathrm{AX}$ in tyrosine 142 (Tyr142P)[64, 65]. As it inhibits the binding of repair factors to $\gamma \mathrm{H} 2 \mathrm{AX}$ and promotes the recruitment of pro-apoptotic factors such as JNK1 [64]. On the other hand, loss of H2AX Tyr142P, alters the kinetics of $\gamma \mathrm{H} 2 \mathrm{AX}$ in response to DNA damage [65].

\section{Histone H2AX in cancer}

The association of DNA damage, apoptosis and genome stability with premalignant stages and progression of a tumour is highly recognized. $H 2 A F X$ is located in a chromosome region that frequently exhibits mutations or deletions in a large number of human cancers (11q23), especially in haematopoietic malignancies [66]. Furthermore, a reduction in $H 2 A F X$ gene copy number was verified in MCF7 breast cancer cell line [67] and 
higher methylation status of $H 2 A F X$ promoter leads to a reduction of $\mathrm{H} 2 \mathrm{AX}$ expression in lung squamous cancer [68]. Further, upregulation of H2AX by the clinically approved protein kinase inhibitor Imatinib mesylate triggers apoptosis in gastrointestinal stromal tumour cell lines [69].

Based on $\mathrm{H} 2 \mathrm{AX}$ function in DNA repair and in maintaining DNA stability, the use of H2AX / $\gamma \mathrm{H} 2 \mathrm{AX}$ as marker for early cancer detection, prognosis and

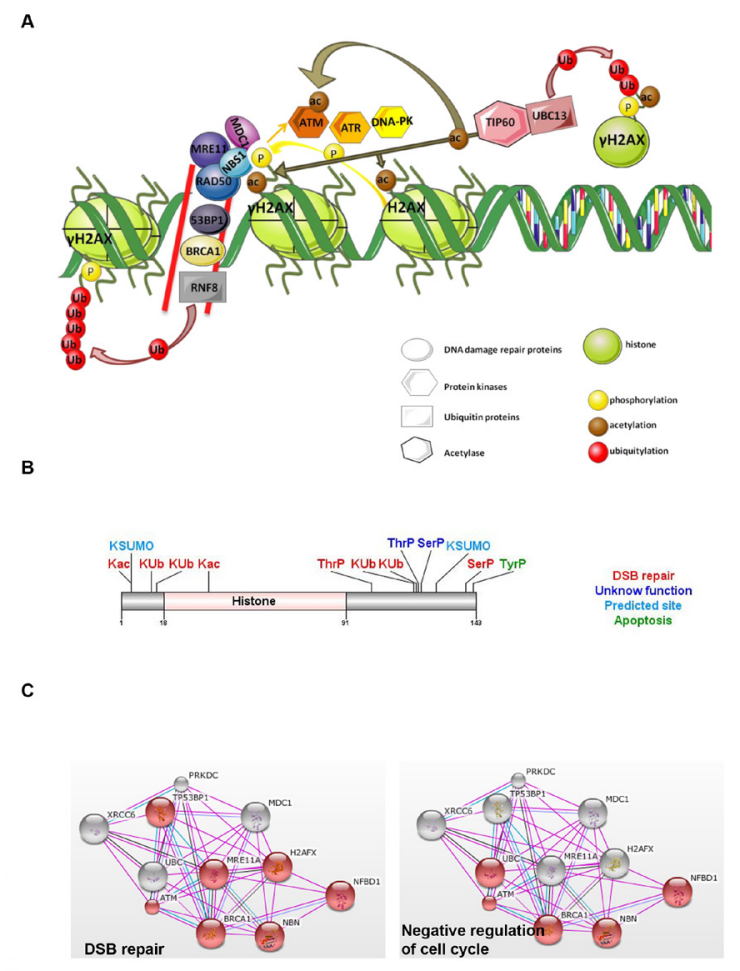

Figure 2: H2AX histone variant. A. Main mechanisms involved in DNA damage repair system (DDR). Upon DNA double strand breaks (DSB; signalled by two red lines), H2AX is recruited and phosphorylated in serine $139(\gamma \mathrm{H} 2 \mathrm{AX})$ by PIKKs, ATM and ATR protein kinases. NBS1 and MDC1 binding to $\gamma \mathrm{H} 2 \mathrm{AX}$ amplify $\mathrm{H} 2 \mathrm{AX}$ phosphorylation through stimulation of ATM and also induce recruitment of DDR repair proteins to sites of DSBs. TIP60 and UBC13 activate H2AX through acetylation and independently of phosphorylation. Acetylated $\mathrm{H} 2 \mathrm{AX}$ is then released from chromatin and ubiquitylated (Ub) by UBC13 and RNF8, leading to formation of ubiquitin chains and recruitment of various DDR proteins containing ubiquitinbinding domains. B. Summary of H2AX protein domain and the multiple regulatory PTMs identified. [47, 48, 55, 58, 59, $64,65,123,124]$. All PTMs related with DSB repair have an indirect role associated with cancer. C. Protein interaction network obtained from String DB (string-db.org) illustrates one of the possible biological processes regulated, as inferred from analysis of public databases. In this case, the protein interaction network shows how different partners regulate H2AX effects on biological processes highlighted in red: double strand break repair (DBS; $\left.\mathrm{p}<1.9 \times 10^{-12}\right)$ or cell cycle $\left(\mathrm{p}<1.04 \times 10^{-4}\right)$. Grids obtained from String DB (string-db.org) using a confidence score of 0.6. Colour key: pink = experimental evidence; blue = evidence from databases; black $=$ co-expression therapeutics has been proposed [70]. Elevated endogenous levels of $\gamma \mathrm{H} 2 \mathrm{AX}$ have been found in various human cancer cell lines such as cervical [71], ovarian [72], breast [73], leukaemia and melanoma, colon, renal, and prostate cancer cell lines [70]. Many therapeutic agents act by introducing sufficient DSBs into cancer cells to activate the apoptotic pathway [74]. Thus, H2AX could also be targeted to promote cancer cell death. For example, latrunculin B, an agent that inhibits actin dynamics, induces $\gamma \mathrm{H} 2 \mathrm{AX}$ formation, leading to $\mathrm{G} 2$ arrest and consequently resulting in MCF-7 breast cancer cell apoptosis [75]. Therefore, quantification of $\gamma \mathrm{H} 2 \mathrm{AX}$ enriched foci to detect DSBs formation, may be a sensitive method to monitor either cancer progression or response to treatment [70].

\section{H2A.Z histone variant}

The variant H2A.Z is highly conserved from yeast to human, with $90 \%$ of its primary sequence preserved among different species, showing only $60 \%$ homology with canonical histone $\mathrm{H} 2 \mathrm{~A}$ [76]. H2A.Z has been one of the most studied H2A variants in recent years. Different studies reported diverse and controversial conclusions regarding alteration in the nucleosome stability by insertion of this variant. Some authors claim that H2A.Z nucleosomes are more stable [77], while others have observed that H2A.Z incorporation destabilizes nucleosome core particles [13, 78]. In yeast, the mechanism by which histone $\mathrm{H} 2 \mathrm{~A}$ is replaced by $\mathrm{H} 2 \mathrm{~A} . \mathrm{Z}$ in the nucleosome is mediated through the action of a multisubunit protein complex, SWR1-Complex, which contains a Swi2/Snf2 paralog [79]. In higher eukaryotes, two SWR1-related multiprotein complexes (SRCAP and p400/TIP60) were described. While the SRCAP chromatin remodeling complex is involved in global H2A.Z deposition activity [80], the p400/TIP60 complex is known to mediate a more localized deposition of H2A.Z [81]. Recently, it was described that the acidic nuclear phosphoprotein 32 kilodalton E (ANP32E), a member of the p400/TIP60 complex, is responsible for the removal and deposition of H2A.Z in the nucleosome [82].

H2A.Z is found in approximately $10 \%$ of mammalian nucleosomes and participates in different biological processes such as cell cycle and DNA replication [83], DNA repair [84], spermatogenesis [85], chromosome segregation [86], centromere structure [87], transcription regulation [88-91], and maintenance of heterochromatic/euchromatic status [92, 93]. However, its role in transcriptional regulation is complex since it has been reported to function both as a transcriptional repressor and activator. The apparently contradictory roles of H2A.Z in vivo might be explained by different combinations of H2A.Z with other epigenetic regulators, PTMs on H2A.Z (Fig. 3A) and interaction with chromatin binding proteins (Fig. 2B) [94]. Acetylated H2A.Z is enriched at the 5' regions of active genes in yeast and vertebrates $[95,96]$, 
whereas ubiquitylated $\mathrm{H} 2 \mathrm{~A} . \mathrm{Z}$ associates with facultative heterochromatin [97], and monomethylation of H2A.Z at $\mathrm{K} 7$ by the lysine methyltransferase SETD6 has been suggested as a marker of cellular differentiation [98].

\section{Histone H2A.Z in cancer}

A possible role for $\mathrm{H} 2 \mathrm{~A} . \mathrm{Z}$ in cancer was first reported using genome wide gene expression profiling where overexpression of H2A.Z was observed in sporadic colorectal tumors [99]. Undifferentiated cancers show $H 2 A F Z$ overexpression compared to well differentiated cancers [100] and overexpression of this histone variant was also reported in genitourinary cancers, such as prostate [101] and bladder cancer [102]. Breast cancer is where H2A.Z role has been best characterized, with its overexpression correlating with lymph node metastasis in primary breast cancer [103], and overexpression also observed in late stages of the disease [104]. The correlation between H2A.Z levels and short patient overall survival suggests that this histone variant might be a biomarker of tumor progression.

H2A.Z gene is under the positive control of c-Myc (Fig. 3B) and therefore might be an important indirect target for breast cancer therapy [105]. H2A.Z positively regulates estrogen receptor $(\mathrm{ER}) \alpha$-dependent transcription and estrogen simulation of cell proliferation [106]. Yet, in MCF7 cells, H2A.Z overexpression also promotes cellular proliferation under low estrogen levels and upon treatment with the ER antagonist tamoxifen, which suggests that

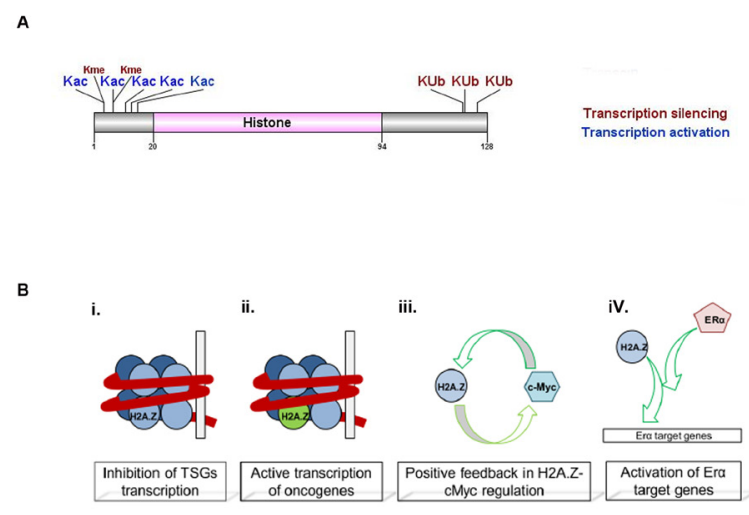

Figure 3: H2A.Z histone variant structure and function. A. H2A.Z protein domain and reported PTMs [93, $94,97,98,109]$. Those hPTMs with a function in cancer are in larger font. B. H2A.Z in cell proliferation. Incorporation of nonacetylated H2A.Z into nucleosomes inhibits tumor suppressor genes (TSG) transcription (i) and is found in actively transcribed oncogenes in its acetylation form (ii). One example is H2A.Z enrichment in c-Myc promoter, which stimulates its expression, leading to higher c-Myc protein levels which in turn activates H2A.Z transcription (iii). H2A.Z is found enriched in ER $\alpha$ target genes and is necessary for $\mathrm{ER} \alpha$ transactivation of proliferation genes in breast cancer (iv). proliferation induced by H2A.Z overrides the inhibitory effects of tamoxifen on gene transactivation by ER $\alpha$ and may play a role in endocrine resistance [107].

$\mathrm{H} 2 \mathrm{~A} . \mathrm{Z}$ is also associated to androgen receptor (AR) gene transactivation and progression of prostate carcinoma (PCa). H2A.Z ubiquitylation in K120, K121 and K125 has been described as present in PCa and associated with transcriptional silencing (Fig. 3A). Deubiquitylation of H2A.Z by ubiquitin-specific protease (USP10) leads to transcriptional activation of the AR-regulated $P S A$ and $K L K 3$ genes [97]. A significant increase of $\mathrm{H} 2 \mathrm{~A} . \mathrm{Z}$ was found in castration-resistant $\mathrm{LNCaP}$ xenograft model [108]. Furthermore, since PCa patients submitted to androgen-deprivation therapy tend to express more H2A.Z over time, it has been suggested that the elevated expression of $\mathrm{H} 2 \mathrm{~A} . \mathrm{Z}$ might be indicative of primary $\mathrm{PCa}$ progression to androgen-independence [108]. A recent study in PCa cell lines evaluated how H2A.Z and its acetylation in K4, K7 and K11 (acH2A.Z) positively regulates transcription of oncogenes and showed that acH2A.Z mutually excluded DNA methylation and the deposition of the H3K27me3 mark within the promoter region [109]. Consequently, acH2A.Z tended to accumulate within the TSS of active genes and was tightly associated with active gene transcription [109]. In line with this, H2A.Z deacetylation is most prevalent in nucleosomes next to the TSS and correlates with lower gene transcription activity including that of tumor suppressor genes [109]. More recently, Baptista, et al. using PCa cell lines showed that H2A.Z regulates its own expression by increasing its accumulation nearby the TSS of the $H 2 A F Z$ gene, while its regulation is impaired by decreased expression and protein levels of the histone deacetylase NAD-dependent protein deacetylase sirtuin-1 (SIRT1), which is necessary to maintain H2A.Z levels [101]. Furthermore, effective restoring of SIRT1 function by epigenetic modifying drugs in conjunction with enzymatic modulators lead to proteasomal degradation of H2A.Z and of its target/regulator c-Myc. Therefore, SIRT1 activation, emerged as a promising tool for targeted therapy of endocrine-resistant $\mathrm{PCa}$ patients through reduction of H2A.Z [101].

A dependence of H2A.Z for cancer cell proliferation, viability and progression into cell cycle was showed in the osteosarcoma U2OS cell line with H2A.Z depletion; However, the same was not observed in relation to DNA repair [110]. These results seems to be contradictory, since $\mathrm{Xu}$ et al described that H2A.Z exchange at DSBs shifts the chromatin to an open conformation required for loading some of the DDR proteins [84]. The authors suggested that the p53 status and the cell line may be key to explain these contradictory results [110]. 


\section{Other $\mathrm{H} 2 \mathrm{~A}$ variants in cancer}

Additionally, there are some $\mathrm{H} 2 \mathrm{~A}$ variants altered in cancer but with no associated function identified. For example, during sequential development of hepatocellular carcinoma, the major histone H2A variant H2A.1 (HIST2H2AAl) is overexpressed, and H2A.2 (HIST2H2AA3) is decreased at the protein and mRNA levels [111]. The histone variant $\mathrm{H} 2 \mathrm{~A} 1 \mathrm{C}$ was described as overexpressed in MCF-7 cell line along with the silencing of the oncogenic protein phosphatase magnesium-dependent 1 delta (PPM1D) [112]. Moreover, in acute myeloid leukemia, reduced expression of the HIST1H2AC locus leads to increased rates of cell proliferation and tumorigenicity [113], also supporting a loss of function for $\mathrm{H} 2 \mathrm{~A} 1 \mathrm{C}$ during cancer progression. Lastly, H2AFJ has been subject of controversial findings, with downregulation reported in melanocytic tumor lesions [114] and overexpression in breast cancers with 12 p13 regional copy number gain compared with a panel of normal mammary epithelial cells [115].

\section{Future challenges in the study of $\mathrm{H} 2 \mathrm{~A}$ family members}

Methods using antibodies or DNA probes are the primary tools used for molecular and biochemical investigation. Since many members of the H2A family share high sequence homology (Supplementary Tables 1 and 2), the lack of reagents with high-specificity for individual variants has hindered studies on expression and function of several H2A variants. Some variants share up to $98 \%$ homology and therefore, even approaches designed to identify non-homologous regions are restricted. The high homology in the base pair sequence and existence of duplicated genes poses a methodological draw-back for the design of probes for RNA quantification, alignment of RNA-seq data and gene expression silencing using siRNAs. In addition, the high similarity of epitopes in $\mathrm{H} 2 \mathrm{~A}$ variants and the variety of PTMs on these molecules complicate the generation of specific antibodies adding to the difficulty of finding high quality antibodies for H2A variant quantification and chromatin immunoprecipitation (ChIP / ChIP-Seq) analysis. Consequently, and not surprisingly, research has concentrated on those variants which are less conserved and for which it has been easier to obtain specific detection reagents.

Mass spectrometry (MS) has become widely used to analyze histone variants. MS has an advantage over the limitations posed by immunological reagents and has emerged as a promising complementary analytical strategy not only to identify known and novel PTMs on proteins, but also for their relative quantification [116119]. Yet, MS also has its limitations. For instance, some histone $\mathrm{H} 2 \mathrm{~A}$ family members differ in sequence by as little as one amino acid residue which can result in false positive identifications by attribution of multiples of $14 \mathrm{Da}$ mass shifts due to the amino acid differences between the variants which is also traditionally assigned as methylation [120]. The recent advent of high-resolution mass spectrometry (possible with modern mass spectrometers, with a resolution that allows accurate determination of the mass corresponding to a molecular ion), in combination with different strategies for peptide fragment dissociation, electron capture dissociation (ECD) and electron transfer dissociation (ETD) has increased the relevance of MSbased PTM characterization in unveiling the histone code [121]. Indeed, the high mass accuracy afforded by high-resolution MS data greatly increases the confidence in assigning a protein modification. For example, the difference in mass $(\Delta \mathrm{m})$ of $14 \mathrm{Da}$, attributed to Glu->Asp and also to an aminoacid methylation, can be discerned using high-resolution MS since Glu->Asp presents a $\Delta \mathrm{m}$ $14.015650 \mathrm{Da})$ and methylation presents a $\Delta \mathrm{m} 14.016650$ Da). Furthermore, histone variant analysis is highly dependent on liquid chromatography separation whose use is critical in the case of modified histone peptides from a complex sample mixture of a wide concentration range -including large peptides with identical amino acid sequences modified in slightly different waysand which result in many isobaric structural isomers [122]. Nevertheless, despite these drawbacks, the high throughput tools available in MS labs allow a sensitive and reproducible histone profiling that will be of great value for exploring variants and their PTMs and which can readily be applied to clinical or pharmaceutical studies.

In summary, the immunological limitations for studying the expression and function of $\mathrm{H} 2 \mathrm{~A}$ variants make it a challenging field of research. There has been considerable progress made, yet overcoming these difficulties will require improving combinatorial mass spectral methods to bypass the necessity for immunological reagents. In addition, site-directed mutagenesis is also one option for functional analysis to uncover the specific cellular functions of each $\mathrm{H} 2 \mathrm{~A}$ variant and their respective PTMs.

\section{CONCLUSION}

Substitution of canonical H2A by its non-allelic variants modifies nucleosome biophysical properties, chromatin structure and function. Epigenetic alterations preceding cancer disease or evolving alongside progression appear related to $\mathrm{H} 2 \mathrm{~A}$ variant replacement. Further, PTMs, at the inter-phase of histone function and histone differential protein interactions with chromatin remodelers and transcription factors contribute to expression of genes important for DNA repair, redox metabolism, proliferation, survival and metastasis. Much progress has been made in understanding the functions of several $\mathrm{H} 2 \mathrm{~A}$ variants and to describe their alterations in 
cancer. These results lead to propose non-canonical $\mathrm{H} 2 \mathrm{~A}$ variants as markers of disease progression and response to cancer therapy. Notwithstanding the difficult task of finding highly specific antibodies, future work should be done to validate these data in a broader number of cancer cases, as well as developing highly sensitive MS-based methodologies to discriminate $\mathrm{H} 2 \mathrm{~A}$ variants with high sequence homology and for which specific detection reagents are lacking.

\section{List of Abbreviations}

Ac - acetylated

ANP32E - acidic nuclear phosphoprotein 32

kilodalton $\mathrm{E}$

AR - androgen receptor

ATM - ataxia telangiectasia mutated

ATR - ataxia telangiectasia and Rad3-related

BRCA1 - Breast Cancer 1, Early Onset

CAD - caspase-activated DNase

CDK8 - cyclin-dependent kinase 8

c-Fos - FBJ Murine Osteosarcoma Viral Oncogene

Homolog

ChIP - chromatin immunoprecipitation

DDR - DNA damage repair

DNA-PK - DNA-dependent protein kinase

DSBs - DNA double strand breaks

ERBB2 - V-Erb-B2 Avian Erythroblastic Leukemia

Viral Oncogene Homolog 2

Eya - eyes absent homolog

GFOD1 - Glucose-Fructose Oxidoreductase

Domain Containing 1

HAO1 - Hydroxyacid Oxidase (Glycolate Oxidase)

1

hPTMs - histone post-translational modifications

IR - ionizing radiation

JNK - c-Jun NH2-terminal kinase

$\mathrm{K}$ - lysine

protein 1

MDC1 - mediator of DNA damage checkpoint

MS - Mass spectrometry

NAD - Nicotinamide adenine dinucleotide

NBS1 - Nijmegen breakage syndrome 1 (nibrin)

$\mathrm{P}$ - phosphorylation

PARP-1 - Poly (ADP-Ribose) Polymerase 1

$\mathrm{PCa}$ - prostate carcinoma

PIKKs - phosphatidylinositol-3 kinase-like kinases

PPM1D - oncogenic protein phosphatase

magnesium-dependent 1 delta

RFESD - Rieske (Fe-S) Domain Containing Ligase

RNF8 - Ring Finger Protein 8, E3 Ubiquitin Protein

Ser - serine

SOD3 - Superoxide Dismutase 3, Extracellular

SPOP - speckle-Type POZ Protein

Thr - threonine
TSSs - transcription start sites

Tyr - tirosine

$\mathrm{Ub}$ - ubiquitylation

UBC13 - Ubiquitin-Conjugating Enzyme E2N

USP10 - ubiquitin-specific protease

$X i$ - inactive $\mathrm{X}$ chromosome

53BP1 - p53-binding protein 1

\section{Competing interests}

The authors declare that they have no competing interests

\section{Authors' information}

LM: is a Research Fellow currently studying expression and functionality of different $\mathrm{H} 2 \mathrm{~A}$ histones in mammary gland development and breast cancer.

TB: is a PhD student currently at Institut de Génétique et de Biologie Moléculaire et Cellulaire IGBMC, Strasbourg, France and former MSc student at Cancer Biology \& Epigenetics group at the Portuguese Oncology Institute- Porto

FA, PhD: is the Head of the Mass Spectrometry Centre at the University of Aveiro.

$\mathrm{RV}, \mathrm{PhD}$ : coordinates the proteomics laboratory at QOPNA-University of Aveiro. His work is focused in the development of proteomics tools for biological sample characterization from different pathophysiological conditions.

CJ, PhD: coordinates the Cancer Biology \& Epigenetics group at the Portuguese Oncology InstitutePorto and is invited associate Professor at the Department of Pathology \& Molecular Immunology at the Institute of Biomedical Sciences Abel Salazar (ICBAS) of University of Porto

LAH, PhD: coordinates the Hormones and Cancer group at the Mass Spectrometry Centre, QOPNA-University of Aveiro. Her work is focussed in understanding epigenetic mechanisms that regulate cell proliferation and differentiation.

\section{ACKNOWLEDGEMENTS}

This work was supported by Federal funds through Programa Operacional Temático Factores de Competitividade (COMPETE) with co-participation from the European Community Fund (FEDER) and national funds through Fundação para a Ciência e Tecnología (FCT) under the projects PTDC/SAU-ONC/118346/2010 (LAH); Project Ciência 2008 (LAH). The Mass Spectrometry Center, within the Organic Chemistry and Natural Products (QOPNA) research unit is founded by the University of Aveiro, FCT, European Union, QREN, FEDER and COMPETE project PEst-C/QUI/ 
UI0062/2013. This work was also supported by CENTRO07-ST24-FEDER-002034.

\section{REFERENCES}

1. Luger K, Mader AW, Richmond RK, Sargent DF and Richmond TJ. Crystal structure of the nucleosome core particle at 2.8 A resolution. Nature. 1997; 389(6648):251260.

2. Marc F, Sandman K, Lurz R and Reeve JN. Archaeal histone tetramerization determines DNA affinity and the direction of DNA supercoiling. J Biol Chem. 2002; 277(34):30879-30886.

3. Michael R. Cummings WSK. (2005). Concepts of Genetics.

4. Ausio J. Histone variants--the structure behind the function. Brief Funct Genomic Proteomic. 2006; 5(3):228-243.

5. Strahl BD and Allis CD. The language of covalent histone modifications. Nature. 2000; 403(6765):41-45.

6. Bonenfant D, Coulot M, Towbin H, Schindler P and van Oostrum J. Characterization of histone $\mathrm{H} 2 \mathrm{~A}$ and $\mathrm{H} 2 \mathrm{~B}$ variants and their post-translational modifications by mass spectrometry. Mol Cell Proteomics. 2006; 5(3):541-552.

7. Albert L. Lehninger DLN, Michael M. Cox. (2008). Lenhinger Principles of Biochemistry: W.H. Freeman, 2008).

8. Robbins E and Borun TW. The cytoplasmic synthesis of histones in hela cells and its temporal relationship to DNA replication. Proc Natl Acad Sci U S A. 1967; 57(2):409416.

9. Kurat CF, Lambert JP, van Dyk D, Tsui K, van Bakel H, Kaluarachchi S, Friesen H, Kainth P, Nislow C, Figeys D, Fillingham $\mathrm{J}$ and Andrews BJ. Restriction of histone gene transcription to $\mathrm{S}$ phase by phosphorylation of a chromatin boundary protein. Genes Dev. 2011; 25(23):2489-2501.

10. Chen $\mathrm{P}, \mathrm{Zhao} \mathrm{J}$ and $\mathrm{Li} \mathrm{G}$. Histone variants in development and diseases. J Genet Genomics. 2013; 40(7):355-365.

11. Ahmad $\mathrm{K}$ and Henikoff $\mathrm{S}$. The histone variant H3.3 marks active chromatin by replication-independent nucleosome assembly. Mol Cell. 2002; 9(6):1191-1200.

12. Recinos RF, Kirchhoff LV and Donelson JE. Cell cycle expression of histone genes in Trypanosoma cruzi. Molecular and Biochemical Parasitology. 2001; 113(2):215222.

13. Suto RK, Clarkson MJ, Tremethick DJ and Luger K. Crystal structure of a nucleosome core particle containing the variant histone H2A.Z. Nat Struct Biol. 2000; 7(12):11211124.

14. Chakravarthy S, Bao Y, Roberts VA, Tremethick D and Luger K. Structural characterization of histone H2A variants. Cold Spring Harb Symp Quant Biol. 2004; 69:227234.

15. Pehrson JR and Fuji RN. Evolutionary conservation of histone macroH2A subtypes and domains. Nucleic Acids Res. 1998; 26(12):2837-2842.
16. Waterborg JH. Evolution of histone H3: emergence of variants and conservation of post-translational modification sites. Biochem Cell Biol. 2012; 90(1):79-95.

17. Wu RS, Nishioka D and Bonner WM. Differential conservation of histone 2A variants between mammals and sea urchins. J Cell Biol. 1982; 93(2):426-431.

18. Vardabasso C, Hasson D, Ratnakumar K, Chung CY, Duarte LF and Bernstein E. Histone variants: emerging players in cancer biology. Cell Mol Life Sci. 2014; 71(3):379-404.

19. Bonisch $\mathrm{C}$ and Hake SB. Histone H2A variants in nucleosomes and chromatin: more or less stable? Nucleic Acids Res. 2012; 40(21):10719-10741.

20. Pehrson JR and Fried VA. MacroH2A, a core histone containing a large nonhistone region. Science. 1992; 257(5075):1398-1400.

21. Chadwick BP and Willard HF. Histone H2A variants and the inactive $\mathrm{X}$ chromosome: identification of a second macroH2A variant. Hum Mol Genet. 2001; 10(10):11011113.

22. Bernstein E, Muratore-Schroeder TL, Diaz RL, Chow JC, Changolkar LN, Shabanowitz J, Heard E, Pehrson JR, Hunt DF and Allis CD. A phosphorylated subpopulation of the histone variant macroH2A1 is excluded from the inactive $\mathrm{X}$ chromosome and enriched during mitosis. Proc Natl Acad Sci U S A. 2008; 105(5):1533-1538.

23. Ogawa Y, Ono T, Wakata Y, Okawa K, Tagami H and Shibahara KI. Histone variant macroH2A1.2 is monoubiquitinated at its histone domain. Biochem Biophys Res Commun. 2005; 336(1):204-209.

24. Chu F, Nusinow DA, Chalkley RJ, Plath K, Panning B and Burlingame AL. Mapping post-translational modifications of the histone variant MacroH2A1 using tandem mass spectrometry. Mol Cell Proteomics. 2006; 5(1):194-203.

25. Hernandez-Munoz I, Lund AH, van der Stoop P, Boutsma E, Muijrers I, Verhoeven E, Nusinow DA, Panning B, Marahrens $\mathrm{Y}$ and van Lohuizen M. Stable X chromosome inactivation involves the PRC1 Polycomb complex and requires histone MACROH2A1 and the CULLIN3/SPOP ubiquitin E3 ligase. Proc Natl Acad Sci U S A. 2005; 102(21):7635-7640.

26. Costanzi $\mathrm{C}$ and Pehrson JR. Histone macroH2A1 is concentrated in the inactive $\mathrm{X}$ chromosome of female mammals. Nature. 1998; 393(6685):599-601.

27. Costanzi $\mathrm{C}$ and Pehrson JR. MACROH2A2, a new member of the MARCOH2A core histone family. J Biol Chem. 2001; 276(24):21776-21784.

28. Angelov D, Molla A, Perche PY, Hans F, Cote J, Khochbin $\mathrm{S}$, Bouvet $\mathrm{P}$ and Dimitrov $\mathrm{S}$. The histone variant macroH2A interferes with transcription factor binding and SWI/SNF nucleosome remodeling. Mol Cell. 2003; 11(4):1033-1041.

29. Gamble MJ, Frizzell KM, Yang C, Krishnakumar R and Kraus WL. The histone variant macroH2A1 marks repressed autosomal chromatin, but protects a subset of its 
target genes from silencing. Genes Dev. 2010; 24(1):21-32.

30. Zhang R, Poustovoitov MV, Ye X, Santos HA, Chen W, Daganzo SM, Erzberger JP, Serebriiskii IG, Canutescu AA, Dunbrack RL, Pehrson JR, Berger JM, Kaufman $\mathrm{PD}$ and Adams PD. Formation of MacroH2A-containing senescence-associated heterochromatin foci and senescence driven by ASF1a and HIRA. Dev Cell. 2005; 8(1):19-30.

31. Buschbeck M, Uribesalgo I, Wibowo I, Rue P, Martin D, Gutierrez A, Morey L, Guigo R, Lopez-Schier H and Di Croce $\mathrm{L}$. The histone variant macroH2A is an epigenetic regulator of key developmental genes. Nat Struct Mol Biol. 2009; 16(10):1074-1079.

32. Changolkar LN, Costanzi C, Leu NA, Chen D, McLaughlin KJ and Pehrson JR. Developmental changes in histone macroH2A1-mediated gene regulation. Mol Cell Biol. 2007; 27(7):2758-2764.

33. Rasmussen TP, Huang T, Mastrangelo MA, Loring J, Panning B and Jaenisch R. Messenger RNAs encoding mouse histone macroH2A1 isoforms are expressed at similar levels in male and female cells and result from alternative splicing. Nucleic Acids Res. 1999; 27(18):36853689 .

34. Pehrson JR, Costanzi C and Dharia C. Developmental and tissue expression patterns of histone macroH2A1 subtypes. J Cell Biochem. 1997; 65(1):107-113.

35. Kustatscher G, Hothorn M, Pugieux C, Scheffzek K and Ladurner AG. Splicing regulates NAD metabolite binding to histone macroH2A. Nat Struct Mol Biol. 2005; 12(7):624-625.

36. Kapoor A, Goldberg MS, Cumberland LK, Ratnakumar K, Segura MF, Emanuel PO, Menendez S, Vardabasso C, Leroy G, Vidal CI, Polsky D, Osman I, Garcia $\mathrm{BA}$, Hernando $\mathrm{E}$ and Bernstein E. The histone variant macroH2A suppresses melanoma progression through regulation of CDK8. Nature. 2010; 468(7327):1105-1109.

37. Li X, Kuang J, Shen Y, Majer MM, Nelson CC, Parsawar K, Heichman KA and Kuwada SK. The atypical histone macroH2A1.2 interacts with HER-2 protein in cancer cells. J Biol Chem. 2012; 287(27):23171-23183.

38. Sporn JC and Jung B. Differential regulation and predictive potential of MacroH2A1 isoforms in colon cancer. Am J Pathol. 2012; 180(6):2516-2526.

39. Sporn JC, Kustatscher G, Hothorn T, Collado M, Serrano M, Muley T, Schnabel P and Ladurner AG. Histone macroH2A isoforms predict the risk of lung cancer recurrence. Oncogene. 2009; 28(38):3423-3428.

40. Novikov L, Park JW, Chen H, Klerman H, Jalloh AS and Gamble MJ. QKI-mediated alternative splicing of the histone variant MacroH2A1 regulates cancer cell proliferation. Mol Cell Biol. 2011; 31(20):4244-4255.

41. Gamble MJ and Kraus WL. Multiple facets of the unique histone variant macroH2A: from genomics to cell biology. Cell Cycle. 2010; 9(13):2568-2574.

42. Dardenne E, Pierredon S, Driouch K, Gratadou L, Lacroix-
Triki M, Espinoza MP, Zonta E, Germann S, Mortada H, Villemin JP, Dutertre M, Lidereau R, Vagner S and Auboeuf D. Splicing switch of an epigenetic regulator by RNA helicases promotes tumor-cell invasiveness. Nat Struct Mol Biol. 2012; 19(11):1139-1146.

43. Rogakou EP, Pilch DR, Orr AH, Ivanova VS and Bonner WM. DNA double-stranded breaks induce histone H2AX phosphorylation on serine 139. J Biol Chem. 1998; 273(10):5858-5868.

44. Mannironi C, Bonner WM and Hatch CL. H2A.X. a histone isoprotein with a conserved $\mathrm{C}$-terminal sequence, is encoded by a novel mRNA with both DNA replication type and polyA 3' processing signals. Nucleic Acids Res. 1989; 17(22):9113-9126.

45. Bonner WM, Redon CE, Dickey JS, Nakamura AJ, Sedelnikova OA, Solier S and Pommier Y. GammaH2AX and cancer. Nat Rev Cancer. 2008; 8(12):957-967.

46. Paull TT, Rogakou EP, Yamazaki V, Kirchgessner CU, Gellert $\mathrm{M}$ and Bonner WM. A critical role for histone $\mathrm{H} 2 \mathrm{AX}$ in recruitment of repair factors to nuclear foci after DNA damage. Curr Biol. 2000; 10(15):886-895.

47. Jiang $\mathrm{X}, \mathrm{Xu} \mathrm{Y}$ and Price BD. Acetylation of $\mathrm{H} 2 \mathrm{AX}$ on lysine 36 plays a key role in the DNA double-strand break repair pathway. FEBS Lett. 2010; 584(13):2926-2930.

48. Xie A, Odate S, Chandramouly G and Scully R. H2AX post-translational modifications in the ionizing radiation response and homologous recombination. Cell Cycle. 2010; 9(17):3602-3610.

49. Hanasoge S and Ljungman M. H2AX phosphorylation after UV irradiation is triggered by DNA repair intermediates and is mediated by the ATR kinase. Carcinogenesis. 2007; 28(11):2298-2304.

50. Stiff T, Walker SA, Cerosaletti K, Goodarzi AA, Petermann E, Concannon P, O'Driscoll $\mathrm{M}$ and Jeggo PA. ATRdependent phosphorylation and activation of ATM in response to UV treatment or replication fork stalling. Embo J. 2006; 25(24):5775-5782.

51. Stucki $M$ and Jackson SP. gammaH2AX and MDC1: anchoring the DNA-damage-response machinery to broken chromosomes. DNA Repair. 2006; 5(5):534-543.

52. Lou Z, Minter-Dykhouse K, Franco S, Gostissa M, Rivera MA, Celeste A, Manis JP, van Deursen J, Nussenzweig A, Paull TT, Alt FW and Chen J. MDC1 maintains genomic stability by participating in the amplification of ATM-dependent DNA damage signals. Mol Cell. 2006; 21(2):187-200.

53. Stucki M, Clapperton JA, Mohammad D, Yaffe MB, Smerdon SJ and Jackson SP. MDC1 directly binds phosphorylated histone $\mathrm{H} 2 \mathrm{AX}$ to regulate cellular responses to DNA double-strand breaks. Cell. 2005; 123(7):12131226.

54. Kobayashi J. Molecular mechanism of the recruitment of NBS1/hMRE11/hRAD50 complex to DNA double-strand breaks: NBS1 binds to gamma-H2AX through FHA/BRCT 
domain. J Radiat Res. 2004; 45(4):473-478.

55. Ikura $\mathrm{T}$, Tashiro S, Kakino A, Shima H, Jacob N, Amunugama R, Yoder K, Izumi S, Kuraoka I, Tanaka K, Kimura H, Ikura M, Nishikubo S, Ito T, Muto A, Miyagawa K, et al. DNA damage-dependent acetylation and ubiquitination of $\mathrm{H} 2 \mathrm{AX}$ enhances chromatin dynamics. Mol Cell Biol. 2007; 27(20):7028-7040.

56. Mailand N, Bekker-Jensen S, Faustrup H, Melander F, Bartek J, Lukas C and Lukas J. RNF8 ubiquitylates histones at DNA double-strand breaks and promotes assembly of repair proteins. Cell. 2007; 131(5):887-900.

57. Huen MS, Grant R, Manke I, Minn K, Yu X, Yaffe MB and Chen J. RNF8 transduces the DNA-damage signal via histone ubiquitylation and checkpoint protein assembly. Cell. 2007; 131(5):901-914.

58. Gatti M, Pinato S, Maspero E, Soffientini P, Polo S and Penengo L. A novel ubiquitin mark at the N-terminal tail of histone H2As targeted by RNF168 ubiquitin ligase. Cell Cycle. 2012; 11(13):2538-2544.

59. Mattiroli F, Vissers JH, van Dijk WJ, Ikpa P, Citterio E, Vermeulen W, Marteijn JA and Sixma TK. RNF168 ubiquitinates $\mathrm{K} 13-15$ on $\mathrm{H} 2 \mathrm{~A} / \mathrm{H} 2 \mathrm{AX}$ to drive DNA damage signaling. Cell. 2012; 150(6):1182-1195.

60. Doil C, Mailand N, Bekker-Jensen S, Menard P, Larsen DH, Pepperkok R, Ellenberg J, Panier S, Durocher D, Bartek J, Lukas J and Lukas C. RNF168 binds and amplifies ubiquitin conjugates on damaged chromosomes to allow accumulation of repair proteins. Cell. 2009; 136(3):435446.

61. Leung JW, Agarwal P, Canny MD, Gong F, Robison AD, Finkelstein IJ, Durocher D and Miller KM. Nucleosome acidic patch promotes RNF168- and RING1B/BMI1dependent $\mathrm{H} 2 \mathrm{AX}$ and $\mathrm{H} 2 \mathrm{~A}$ ubiquitination and DNA damage signaling. PLoS Genet. 2014; 10(3).

62. Lu C, Zhu F, Cho YY, Tang F, Zykova T, Ma WY, Bode $\mathrm{AM}$ and Dong Z. Cell apoptosis: requirement of H2AX in DNA ladder formation, but not for the activation of caspase-3. Mol Cell. 2006; 23(1):121-132.

63. Rogakou EP, Nieves-Neira W, Boon C, Pommier Y and Bonner WM. Initiation of DNA fragmentation during apoptosis induces phosphorylation of $\mathrm{H} 2 \mathrm{AX}$ histone at serine 139. J Biol Chem. 2000; 275(13):9390-9395.

64. Cook PJ, Ju BG, Telese F, Wang X, Glass CK and Rosenfeld MG. Tyrosine dephosphorylation of H2AX modulates apoptosis and survival decisions. Nature. 2009; 458(7238):591-596.

65. Xiao A, Li H, Shechter D, Ahn SH, Fabrizio LA, Erdjument-Bromage $\mathrm{H}$, Ishibe-Murakami S, Wang B, Tempst P, Hofmann K, Patel DJ, Elledge SJ and Allis CD. WSTF regulates the H2A.X DNA damage response via a novel tyrosine kinase activity. Nature. 2009; 457(7225):5762.

66. Bassing $\mathrm{CH}$, Suh H, Ferguson DO, Chua KF, Manis J, Eckersdorff M, Gleason M, Bronson R, Lee C and Alt
FW. Histone H2AX: a dosage-dependent suppressor of oncogenic translocations and tumors. Cell. 2003; 114(3):359-370.

67. Srivastava N, Gochhait S, Gupta P and Bamezai RN. Copy number alterations of the H2AFX gene in sporadic breast cancer patients. Cancer Genet Cytogenet. 2008; 180(2):121128.

68. Castro M, Grau L, Puerta P, Gimenez L, Venditti J, Quadrelli S and Sanchez-Carbayo M. Multiplexed methylation profiles of tumor suppressor genes and clinical outcome in lung cancer. J Transl Med. 2010; 8(86):14795876.

69. Liu Y, Tseng M, Perdreau SA, Rossi F, Antonescu C, Besmer P, Fletcher JA, Duensing $\mathrm{S}$ and Duensing $\mathrm{A}$. Histone $\mathrm{H} 2 \mathrm{AX}$ is a mediator of gastrointestinal stromal tumor cell apoptosis following treatment with imatinib mesylate. Cancer Res. 2007; 67(6):2685-2692.

70. Sedelnikova OA and Bonner WM. GammaH2AX in cancer cells: a potential biomarker for cancer diagnostics, prediction and recurrence. Cell Cycle. 2006; 5(24):29092913.

71. Banath JP, Macphail SH and Olive PL. Radiation sensitivity, H2AX phosphorylation, and kinetics of repair of DNA strand breaks in irradiated cervical cancer cell lines. Cancer Res. 2004; 64(19):7144-7149.

72. Yu T, MacPhail SH, Banath JP, Klokov D and Olive PL. Endogenous expression of phosphorylated histone H2AX in tumors in relation to DNA double-strand breaks and genomic instability. DNA Repair. 2006; 5(8):935-946.

73. Nagelkerke A, van Kuijk SJ, Sweep FC, Nagtegaal ID, Hoogerbrugge N, Martens JW, Timmermans MA, van Laarhoven HW, Bussink J and Span PN. Constitutive expression of gamma-H2AX has prognostic relevance in triple negative breast cancer. Radiother Oncol. 2011; 101(1):39-45.

74. Helleday T, Petermann E, Lundin C, Hodgson B and Sharma RA. DNA repair pathways as targets for cancer therapy. Nat Rev Cancer. 2008; 8(3):193-204.

75. Shin IJ, Ahn YT, Kim Y, Kim JM and An WG. Actin disruption agents induce phosphorylation of histone H2AX in human breast adenocarcinoma MCF-7 cells. Oncol Rep. 2011; 25(5):1313-1319.

76. Iouzalen N, Moreau J and Mechali M. H2A.ZI, a new variant histone expressed during Xenopus early development exhibits several distinct features from the core histone H2A. Nucleic Acids Res. 1996; 24(20):3947-3952.

77. Park YJ, Dyer PN, Tremethick DJ and Luger K. A new fluorescence resonance energy transfer approach demonstrates that the histone variant $\mathrm{H} 2 \mathrm{AZ}$ stabilizes the histone octamer within the nucleosome. J Biol Chem. 2004; 279(23):24274-24282.

78. Ausio J, Abbott DW, Ivanova VS, Wang XY and Bonner WM. Characterization of the stability and folding of H2A.Z chromatin particles - Implications for transcriptional 
activation. J Biol Chem. 2001; 276(45):41945-41949.

79. Kobor MS, Venkatasubrahmanyam S, Meneghini MD, Gin JW, Jennings JL, Link AJ, Madhani HD and Rine J. A protein complex containing the conserved Swi2/Snf2related ATPase Swr1p deposits histone variant H2A.Z into euchromatin. PLoS Biol. 2004; 2(5):23.

80. Ruhl DD, Jin J, Cai Y, Swanson S, Florens L, Washburn MP, Conaway RC, Conaway JW and Chrivia JC. Purification of a human SRCAP complex that remodels chromatin by incorporating the histone variant $\mathrm{H} 2 \mathrm{~A} . \mathrm{Z}$ into nucleosomes. Biochemistry. 2006; 45(17):5671-5677.

81. Lee K, Lau ZZ, Meredith C and Park JH. Decrease of p400 ATPase complex and loss of H2A.Z within the p21 promoter occur in senescent IMR-90 human fibroblasts. Mech Ageing Dev. 2012; 133(11-12):686-694.

82. Obri A, Ouararhni K, Papin C, Diebold ML, Padmanabhan K, Marek M, Stoll I, Roy L, Reilly PT, Mak TW, Dimitrov $\mathrm{S}$, Romier $\mathrm{C}$ and Hamiche A. ANP32E is a histone chaperone that removes H2A.Z from chromatin. Nature. 2014; 505(7485):648-653.

83. Dhillon N, Oki M, Szyjka SJ, Aparicio OM and Kamakaka RT. H2A.Z functions to regulate progression through the cell cycle. Mol Cell Biol. 2006; 26(2):489-501.

84. Xu Y, Ayrapetov MK, Xu C, Gursoy-Yuzugullu O, Hu Y and Price BD. Histone H2A.Z controls a critical chromatin remodeling step required for DNA double-strand break repair. Mol Cell. 2012; 48(5):723-733.

85. Greaves IK, Rangasamy D, Devoy M, Marshall Graves JA and Tremethick DJ. The $\mathrm{X}$ and $\mathrm{Y}$ chromosomes assemble into H2A.Z-containing [corrected] facultative heterochromatin [corrected] following meiosis. Mol Cell Biol. 2006; 26(14):5394-5405.

86. Rangasamy D, Greaves I and Tremethick DJ. RNA interference demonstrates a novel role for H2A.Z in chromosome segregation. Nat Struct Mol Biol. 2004; 11(7):650-655.

87. Greaves IK, Rangasamy D, Ridgway P and Tremethick DJ. H2A.Z contributes to the unique 3D structure of the centromere. Proc Natl Acad Sci U S A. 2007; 104(2):525530.

88. Larochelle M and Gaudreau L. H2A.Z has a function reminiscent of an activator required for preferential binding to intergenic DNA. Embo J. 2003; 22(17):4512-4522.

89. O'Donnell A, Yang SH and Sharrocks AD. PARP1 orchestrates variant histone exchange in signal-mediated transcriptional activation. EMBO Rep. 2013; 14(12):10841091.

90. Creyghton MP, Markoulaki S, Levine SS, Hanna J, Lodato MA, Sha K, Young RA, Jaenisch R and Boyer LA. H2AZ is enriched at polycomb complex target genes in ES cells and is necessary for lineage commitment. Cell. 2008; 135(4):649-661.

91. Adam M, Robert F, Larochelle M and Gaudreau L. H2A.Z is required for global chromatin integrity and for recruitment of RNA polymerase II under specific conditions. Mol Cell Biol. 2001; 21(18):6270-6279.

92. Meneghini MD, Wu M and Madhani HD. Conserved histone variant H2A.Z protects euchromatin from the ectopic spread of silent heterochromatin. Cell. 2003; 112(5):725-736.

93. Sarcinella E, Zuzarte PC, Lau PN, Draker R and Cheung P. Monoubiquitylation of H2A.Z distinguishes its association with euchromatin or facultative heterochromatin. Mol Cell Biol. 2007; 27(18):6457-6468.

94. Ku M, Jaffe JD, Koche RP, Rheinbay E, Endoh M, Koseki H, Carr SA and Bernstein BE. H2A.Z landscapes and dual modifications in pluripotent and multipotent stem cells underlie complex genome regulatory functions. Genome Biol. 2012; 13(10).

95. Bruce K, Myers FA, Mantouvalou E, Lefevre P, Greaves I, Bonifer C, Tremethick DJ, Thorne AW and Crane-Robinson C. The replacement histone H2A.Z in a hyperacetylated form is a feature of active genes in the chicken. Nucleic Acids Res. 2005; 33(17):5633-5639.

96. Millar CB, Xu F, Zhang K and Grunstein M. Acetylation of H2AZ Lys 14 is associated with genome-wide gene activity in yeast. Genes Dev. 2006; 20(6):711-722.

97. Draker R, Sarcinella E and Cheung P. USP10 deubiquitylates the histone variant H2A.Z and both are required for androgen receptor-mediated gene activation. Nucleic Acids Res. 2011; 39(9):3529-3542.

98. Binda O, Sevilla A, LeRoy G, Lemischka IR, Garcia BA and Richard S. SETD6 monomethylates H2AZ on lysine 7 and is required for the maintenance of embryonic stem cell self-renewal. Epigenetics. 2013; 8(2):177-183.

99. Dunican DS, McWilliam P, Tighe O, Parle-McDermott A and Croke DT. Gene expression differences between the microsatellite instability (MIN) and chromosomal instability (CIN) phenotypes in colorectal cancer revealed by high-density cDNA array hybridization. Oncogene. 2002; 21(20):3253-3257.

100. Rhodes DR, Yu J, Shanker K, Deshpande N, Varambally R, Ghosh D, Barrette T, Pandey A and Chinnaiyan AM. Large-scale meta-analysis of cancer microarray data identifies common transcriptional profiles of neoplastic transformation and progression. Proceedings of the National Academy of Sciences of the United States of America. 2004; 101(25):9309-9314.

101. Baptista T, Graca I, Sousa EJ, Oliveira AI, Costa NR, Costa-Pinheiro P, Amado F, Henrique R and Jeronimo C. Regulation of histone H2A.Z expression is mediated by sirtuin 1 in prostate cancer. Oncotarget. 2013; 29:29.

102. Kim K, Punj V, Choi J, Heo K, Kim JM, Laird PW and An W. Gene dysregulation by histone variant H2A.Z in bladder cancer. Epigenetics \& Chromatin. 2013:34.

103. Hua S, Kallen CB, Dhar R, Baquero MT, Mason CE, Russell BA, Shah PK, Liu J, Khramtsov A, Tretiakova MS, Krausz TN, Olopade OI, Rimm DL and White KP. 
Genomic analysis of estrogen cascade reveals histone variant H2A.Z associated with breast cancer progression. Mol Syst Biol. 2008; 4(188):15.

104. Zucchi I, Mento E, Kuznetsov VA, Scotti M, Valsecchi V, Simionati B, Vicinanza E, Valle G, Pilotti S, Reinbold R, Vezzoni P, Albertini A and Dulbecco R. Gene expression profiles of epithelial cells microscopically isolated from a breast-invasive ductal carcinoma and a nodal metastasis. Proc Natl Acad Sci U S A. 2004; 101(52):18147-18152.

105. Rangasamy D. Histone variant H2A.Z can serve as a new target for breast cancer therapy. Curr Med Chem. 2010; 17(28):3155-3161.

106. Gevry N, Hardy S, Jacques PE, Laflamme L, Svotelis A, Robert F and Gaudreau L. Histone H2A.Z is essential for estrogen receptor signaling. Genes Dev. 2009; 23(13):15221533.

107. Svotelis A, Gevry N, Grondin G and Gaudreau L. H2A.Z overexpression promotes cellular proliferation of breast cancer cells. Cell Cycle. 2010; 9(2):364-370.

108. Dryhurst D, McMullen B, Fazli L, Rennie PS and Ausio J. Histone H2A.Z prepares the prostate specific antigen (PSA) gene for androgen receptor-mediated transcription and is upregulated in a model of prostate cancer progression. Cancer letters. 2012; 315(1):38-47.

109. Valdes-Mora F, Song JZ, Statham AL, Strbenac D, Robinson MD, Nair SS, Patterson KI, Tremethick DJ, Stirzaker C and Clark SJ. Acetylation of H2A.Z is a key epigenetic modification associated with gene deregulation and epigenetic remodeling in cancer. Genome Res. 2012; 22(2):307-321.

110. Taty-Taty GC, Courilleau C, Quaranta M, Carayon A, Chailleux C, Aymard F, Trouche D and Canitrot Y. H2A.Z depletion impairs proliferation and viability but not DNA double-strand breaks repair in human immortalized and tumoral cell lines. Cell Cycle. 2014; 13(3):399-407.

111. Khare SP, Sharma A, Deodhar KK and Gupta S. Overexpression of histone variant H2A.1 and cellular transformation are related in N-nitrosodiethylamineinduced sequential hepatocarcinogenesis. Exp Biol Med. 2011; 236(1):30-35.

112. Parssinen J, Alarmo EL, Khan S, Karhu R, Vihinen M and Kallioniemi A. Identification of differentially expressed genes after PPM1D silencing in breast cancer. Cancer Lett. 2008; 259(1):61-70.

113. Singh R, Mortazavi A, Telu KH, Nagarajan P, Lucas DM, Thomas-Ahner JM, Clinton SK, Byrd JC, Freitas MA and Parthun MR. Increasing the complexity of chromatin: functionally distinct roles for replication-dependent histone $\mathrm{H} 2 \mathrm{~A}$ isoforms in cell proliferation and carcinogenesis. Nucleic Acids Res. 2013; 16:16.

114. de Wit NJ, Rijntjes J, Diepstra JH, van Kuppevelt TH, Weidle UH, Ruiter DJ and van Muijen GN. Analysis of differential gene expression in human melanocytic tumour lesions by custom made oligonucleotide arrays. Br J Cancer.
2005; 92(12):2249-2261.

115. Yao J, Weremowicz S, Feng B, Gentleman RC, Marks JR, Gelman R, Brennan C and Polyak K. Combined cDNA array comparative genomic hybridization and serial analysis of gene expression analysis of breast tumor progression. Cancer Res. 2006; 66(8):4065-4078.

116. Plazas-Mayorca MD, Zee BM, Young NL, Fingerman IM, LeRoy G, Briggs SD and Garcia BA. One-pot shotgun quantitative mass spectrometry characterization of histones. J Proteome Res. 2009; 8(11):5367-5374.

117. Drogaris P, Wurtele $H$, Masumoto $H$, Verreault A and Thibault P. Comprehensive profiling of histone modifications using a label-free approach and its applications in determining structure-function relationships. Anal Chem. 2008; 80(17):6698-6707.

118. Sidoli S, Cheng L and Jensen ON. Proteomics in chromatin biology and epigenetics: Elucidation of post-translational modifications of histone proteins by mass spectrometry. $\mathrm{J}$ Proteomics. 2012.

119. Guedes S, Vitorino R, Domingues MR, Amado F and Domingues P. Glycation and oxidation of histones H2B and H1: in vitro study and characterization by mass spectrometry. Anal Bioanal Chem. 2011.

120. Boyne MT, 2nd, Pesavento JJ, Mizzen CA and Kelleher NL. Precise characterization of human histones in the H2A gene family by top down mass spectrometry. J Proteome Res. 2006; 5(2):248-253.

121. Young NL, DiMaggio PA, Plazas-Mayorca MD, Baliban RC, Floudas CA and Garcia BA. High throughput characterization of combinatorial histone codes. Mol Cell Proteomics. 2009; 8(10):2266-2284.

122. Contrepois K, Ezan E, Mann C and Fenaille F. Ultra-high performance liquid chromatography-mass spectrometry for the fast profiling of histone post-translational modifications. J Proteome Res. 2010; 9(10):5501-5509.

123. Yamagata K and Kitabayashi I. Sirt1 physically interacts with Tip60 and negatively regulates Tip60-mediated acetylation of H2AX. Biochem Biophys Res Commun. 2009; 390(4):1355-1360.

124. Chen WT, Alpert A, Leiter C, Gong F, Jackson SP and Miller KM. Systematic identification of functional residues in mammalian histone H2AX. Mol Cell Biol. 2013; 33(1):111-126.

125. Kalashnikova AA, Winkler DD, McBryant SJ, Henderson RK, Herman JA, DeLuca JG, Luger K, Prenni JE and Hansen JC. Linker histone H1.0 interacts with an extensive network of proteins found in the nucleolus. Nucleic Acids Res. 2013; 41(7):4026-4035.

126. Moorman AF, de Boer PA, Charles R and Lamers WH. The histone $\mathrm{H} 1(0) / \mathrm{H} 5$ variant and terminal differentiation of cells during development of Xenopus laevis. Differentiation. 1987; 35(2):100-107.

127. van Hemert FJ, Jonk LJ and Destree OH. Histone H1(0) mRNA and protein accumulate early during retinoic 
acid induced differentiation of synchronized embryonal carcinoma cells. Mol Biol Rep. 1992; 16(1):33-38.

128. Kostova NN, Srebreva LN, Milev AD, Bogdanova OG, Rundquist I, Lindner $\mathrm{HH}$ and Markov DV. Immunohistochemical demonstration of histone H1(0) in human breast carcinoma. Histochem Cell Biol. 2005; 124(5):435-443.

129. Pieler C, Adolf GR and Swetly P. Accumulation of histone H1(0) during chemically induced differentiation of murine neuroblastoma cells. Eur J Biochem. 1981; 115(2):329-333.

130. Mannironi C, Rossi V, Biondi A, Ubezio P, Masera G, Barbui T and D'Incalci M. Histone H1(0) is synthesized by human lymphocytic leukemia cells but not by normal lymphocytes. Blood. 1987; 70(4):1203-1207.

131. Rousseau D, Khochbin S, Gorka C and Lawrence JJ. Regulation of histone $\mathrm{H} 1(0)$ accumulation during induced differentiation of murine erythroleukemia cells. J Mol Biol. 1991; 217(1):85-92.

132. Rousseau D, Khochbin S, Gorka C and Lawrence JJ. Induction of $\mathrm{H} 1(0)$-gene expression in B16 murine melanoma cells. Eur J Biochem. 1992; 208(3):775-779.

133. Medrzycki M, Zhang Y, McDonald JF and Fan Y. Profiling of linker histone variants in ovarian cancer. Front Biosci. 2012; 17:396-406.

134. Izzo A, Kamieniarz-Gdula K, Ramirez F, Noureen N, Kind J, Manke T, van Steensel B and Schneider R. The genomic landscape of the somatic linker histone subtypes H1.1 to H1.5 in human cells. Cell Rep. 2013; 3(6):2142-2154.

135. Naldi M, Andrisano V, Fiori J, Calonghi N, Pagnotta E, Parolin C, Pieraccini G and Masotti L. Histone proteins determined in a human colon cancer by high-performance liquid chromatography and mass spectrometry. J Chromatogr A. 2006; 29(1):73-81.

136. Konishi A, Shimizu S, Hirota J, Takao T, Fan Y, Matsuoka Y, Zhang L, Yoneda Y, Fujii Y, Skoultchi AI and Tsujimoto Y. Involvement of histone H1.2 in apoptosis induced by DNA double-strand breaks. Cell. 2003; 114(6):673-688.

137. Ruiz-Vela A and Korsmeyer SJ. Proapoptotic histone H1.2 induces CASP-3 and -7 activation by forming a protein complex with CYT c, APAF-1 and CASP-9. FEBS Lett. 2007; 581(18):3422-3428.

138. Gine E, Crespo M, Muntanola A, Calpe E, Baptista MJ, Villamor N, Montserrat E and Bosch F. Induction of histone H1.2 cytosolic release in chronic lymphocytic leukemia cells after genotoxic and non-genotoxic treatment. Haematologica. 2008; 93(1):75-82.

139. Davis CF and Dorak MT. An extensive analysis of the hereditary hemochromatosis gene HFE and neighboring histone genes: associations with childhood leukemia. Ann Hematol. 2010; 89(4):375-384.

140. Popova EY, Grigoryev SA, Fan Y, Skoultchi AI, Zhang SS and Barnstable CJ. Developmentally regulated linker histone H1c promotes heterochromatin condensation and mediates structural integrity of rod photoreceptors in mouse retina. J Biol Chem. 2013; 288(24):17895-17907.

141. Lee LR, Teng PN, Nguyen H, Hood BL, Kavandi L, Wang G, Turbov JM, Thaete LG, Hamilton CA, Maxwell GL, Rodriguez GC, Conrads TP and Syed V. Progesterone enhances calcitriol antitumor activity by upregulating vitamin D receptor expression and promoting apoptosis in endometrial cancer cells. Cancer Prev Res. 2013; 6(7):731743.

142. Li JY, Patterson M, Mikkola HK, Lowry WE and Kurdistani SK. Dynamic distribution of linker histone H1.5 in cellular differentiation. PLoS Genet. 2012; 8(8):30.

143. Hechtman JF, Beasley MB, Kinoshita Y, Ko HM, Hao $\mathrm{K}$ and Burstein DE. Promyelocytic leukemia zinc finger and histone H1.5 differentially stain lowand high-grade pulmonary neuroendocrine tumors: a pilot immunohistochemical study. Hum Pathol. 2013; 44(7):1400-1405.

144. Tanaka M, Hennebold JD, Macfarlane J and Adashi EY. A mammalian oocyte-specific linker histone gene H1oo: homology with the genes for the oocyte-specific cleavage stage histone (cs-H1) of sea urchin and the B4/H1M histone of the frog. Development. 2001; 128(5):655-664.

145. Nayernia K, Meinhardt A, Drabent B, Adham IM, Muller C, Steckel M, Sancken U and Engel W. Synergistic effects of germ cell expressed genes on male fertility in mice. Cytogenet Genome Res. 2003; 103(3-4):314-320.

146. Warneboldt J, Haller F, Horstmann O, Danner BC, Fuzesi L, Doenecke D and Happel N. Histone H1x is highly expressed in human neuroendocrine cells and tumours. BMC Cancer. 2008; 8(388):1471-2407.

147. Seyedin SM and Kistler WS. Isolation and characterization of rat testis H1t. An H1 histone variant associated with spermatogenesis. J Biol Chem. 1980; 255(12):5949-5954.

148. Tanaka H, Matsuoka Y, Onishi M, Kitamura K, Miyagawa Y, Nishimura H, Tsujimura A, Okuyama A and Nishimune Y. Expression profiles and single-nucleotide polymorphism analysis of human HANP1/H1T2 encoding a histone H1like protein. Int J Androl. 2006; 29(2):353-359.

149. Hoyer-Fender S, Costanzi C and Pehrson JR. Histone macroH2A1.2 is concentrated in the XY-body by the early pachytene stage of spermatogenesis. Exp Cell Res. 2000; 258(2):254-260.

150. Tanasijevic B and Rasmussen TP. X chromosome inactivation and differentiation occur readily in ES cells doubly-deficient for macroH2A1 and macroH2A2. PLoS One. 2011; 6(6):30.

151. Bao Y, Konesky K, Park YJ, Rosu S, Dyer PN, Rangasamy D, Tremethick DJ, Laybourn PJ and Luger K. Nucleosomes containing the histone variant H2A.Bbd organize only 118 base pairs of DNA. Embo J. 2004; 23(16):3314-3324.

152. Doyen CM, Montel F, Gautier T, Menoni H, Claudet C, Delacour-Larose M, Angelov D, Hamiche A, Bednar J, Faivre-Moskalenko C, Bouvet P and Dimitrov S. Dissection of the unusual structural and functional properties of the 
variant H2A.Bbd nucleosome. Embo J. 2006; 25(18):42344244.

153. Tolstorukov MY, Goldman JA, Gilbert C, Ogryzko V, Kingston RE and Park PJ. Histone variant H2A.Bbd is associated with active transcription and mRNA processing in human cells. Mol Cell. 2012; 47(4):596-607.

154. Ishibashi T, Li A, Eirin-Lopez JM, Zhao M, Missiaen K, Abbott DW, Meistrich M, Hendzel MJ and Ausio J. H2A.Bbd: an X-chromosome-encoded histone involved in mammalian spermiogenesis. Nucleic Acids Res. 2010; 38(6):1780-1789.

155. Warters RL, Adamson PJ, Pond CD and Leachman SA. Melanoma cells express elevated levels of phosphorylated histone H2AX foci. J Invest Dermatol. 2005; 124(4):807817.

156. Maselli J, Hales BF, Chan P and Robaire B. Exposure to bleomycin, etoposide, and cis-platinum alters rat sperm chromatin integrity and sperm head protein profile. Biol Reprod. 2012; 86(5):1-10.

157. Loe-Mie Y, Lepagnol-Bestel AM, Maussion G, DoronFaigenboim A, Imbeaud S, Delacroix H, Aggerbeck L, Pupko T, Gorwood P, Simonneau M and Moalic JM. SMARCA2 and other genome-wide supported schizophrenia-associated genes: regulation by REST/NRSF, network organization and primate-specific evolution. Hum Mol Genet. 2010; 19(14):2841-2857.

158. Jeung HC, Rha SY, Kim HK, Lim HY, Kim S, Kim SY, Gong SJ, Park CH, Ahn JB, Noh SH and Chung HC. Multiinstitutional phase II study of S-1 monotherapy in advanced gastric cancer with pharmacokinetic and pharmacogenomic evaluations. Oncologist. 2007; 12(5):543-554.

159. Choong LY, Lim S, Chong PK, Wong CY, Shah N and Lim YP. Proteome-wide profiling of the MCF10AT breast cancer progression model. PLoS One. 2010; 5(6):0011030.

160. Grove GW and Zweidler A. Regulation of nucleosomal core histone variant levels in differentiating murine erythroleukemia cells. Biochemistry. 1984; 23(19):44364443.

161. Guo X, Liu W, Pan Y, Ni P, Ji J, Guo L, Zhang J, Wu J, Jiang J, Chen X, Cai Q, Li J, Gu Q, Liu B, Zhu Z and Yu Y. Homeobox gene IRX1 is a tumor suppressor gene in gastric carcinoma. Oncogene. 2010; 29(27):3908-3920.

162. Santoro SW and Dulac C. The activity-dependent histone variant $\mathrm{H} 2 \mathrm{BE}$ modulates the life span of olfactory neurons. Elife. 2012; 1(10):13.

163. Weiss G, Cottrell S, Distler J, Schatz P, Kristiansen G, Ittmann M, Haefliger C, Lesche R, Hartmann A, Corman $\mathrm{J}$ and Wheeler T. DNA methylation of the PITX2 gene promoter region is a strong independent prognostic marker of biochemical recurrence in patients with prostate cancer after radical prostatectomy. J Urol. 2009; 181(4):16781685.

164. Tagami H, Ray-Gallet D, Almouzni G and Nakatani Y. Histone H3.1 and H3.3 complexes mediate nucleosome assembly pathways dependent or independent of DNA synthesis. Cell. 2004; 116(1):51-61.

165. Kawamura M, Akiyama T, Tsukamoto S, Suzuki MG and Aoki F. The expression and nuclear deposition of histone H3.1 in murine oocytes and preimplantation embryos. J Reprod Dev. 2012; 58(5):557-562.

166. Li F, Adam L, Vadlamudi RK, Zhou H, Sen S, Chernoff J, Mandal M and Kumar R. p21-activated kinase 1 interacts with and phosphorylates histone $\mathrm{H} 3$ in breast cancer cells. EMBO Rep. 2002; 3(8):767-773.

167. Tachiwana H, Kagawa W, Osakabe A, Kawaguchi K, Shiga T, Hayashi-Takanaka Y, Kimura $\mathrm{H}$ and Kurumizaka H. Structural basis of instability of the nucleosome containing a testis-specific histone variant, human H3T. Proc Natl Acad Sci U S A. 2010; 107(23):10454-10459.

168. Schenk R, Jenke A, Zilbauer M, Wirth S and Postberg J. $\mathrm{H} 3.5$ is a novel hominid-specific histone $\mathrm{H} 3$ variant that is specifically expressed in the seminiferous tubules of human testes. Chromosoma. 2011; 120(3):275-285.

169. Van Hooser AA, Ouspenski, II, Gregson HC, Starr DA, Yen TJ, Goldberg ML, Yokomori K, Earnshaw WC, Sullivan $\mathrm{KF}$ and Brinkley BR. Specification of kinetochore-forming chromatin by the histone H3 variant CENP-A. J Cell Sci. 2001; 114(Pt 19):3529-3542.

170. Hu H, Liu Y, Wang M, Fang J, Huang H, Yang N, Li Y, Wang J, Yao X, Shi Y, Li G and Xu RM. Structure of a CENP-A-histone H4 heterodimer in complex with chaperone HJURP. Genes Dev. 2011; 25(9):901-906.

171. Sekulic N, Bassett EA, Rogers DJ and Black BE. The structure of (CENP-A-H4)(2) reveals physical features that mark centromeres. Nature. 2010; 467(7313):347-351.

172. Lee SH, Itkin-Ansari P and Levine F. CENP-A, a protein required for chromosome segregation in mitosis, declines with age in islet but not exocrine cells. Aging. 2010; 2(11):785-790.

173. Biermann K, Heukamp LC, Steger K, Zhou H, Franke FE, Guetgemann I, Sonnack V, Brehm R, Berg J, Bastian PJ, Muller SC, Wang-Eckert L, Schorle H and Buttner R. Gene expression profiling identifies new biological markers of neoplastic germ cells. Anticancer Res. 2007; 27(5A):30913100 .

174. Li YM, Liu XH, Cao XZ, Wang L and Zhu MH. [Expression of centromere protein A in hepatocellular carcinoma]. Zhonghua Bing Li Xue Za Zhi. 2007; 36(3):175-178.

175. Tomonaga T, Matsushita K, Yamaguchi S, Oohashi T, Shimada H, Ochiai $\mathrm{T}$, Yoda $\mathrm{K}$ and Nomura $\mathrm{F}$. Overexpression and mistargeting of centromere protein-A in human primary colorectal cancer. Cancer Res. 2003; 63(13):3511-3516.

176. McGovern SL, Qi Y, Pusztai L, Symmans WF and Buchholz TA. Centromere protein-A, an essential centromere protein, is a prognostic marker for relapse in estrogen receptor-positive breast cancer. Breast Cancer Res. 2012; 14(3). 